\title{
Correlation of HER-2/neu Status with Estrogen (ER) \& Progesterone (PR) Receptor in Breast Malignancies
}

${ }^{1}$ Muhammad Afaaq Agha, ${ }^{2}$ Asma Rasheed, ${ }^{2}$ Lubna Humayun, ${ }^{2}$ Sana Tariq,

${ }^{3}$ Nasir Mehmood Chughtai, ${ }^{3}$ Farah Bano Niazi

${ }^{1}$ Department of Forensic Medicine \& Toxicology, Shaikh Zayed Medical Complex, Lahore

${ }^{2}$ Department of Pathology, University College of Medicine \& Dentistry, University of Lahore

${ }^{3}$ Department of Histopathology, Shaikh Zayed Medical Complex, Lahore

\begin{abstract}
Introduction: Prognosis and management of breast cancer are influenced by the classic variables such as histologic type and grade, tumor size, lymph node status, status of hormonal receptors- i.e. estrogen receptor (ER) and progesterone receptor (PR) of the tumor, and, more recently, HER-2/neu (Human Epidermal Growth factor Receptor-2) overexpression. Expression levels of the estrogen, progesterone and HER2/neu receptors which characterize clinically distinct breast tumours have been shown to change during disease progression and in response to systemic therapies. The interrelationship of ER, PR, and HER-2 has come to have a crucial role in the management of breast cancer. Aims \& Objectives: To determine the ER, PR and HER2/neu status in breast malignancies. Place and duration of study: The study was conducted at Department of Histopathology, Federal Postgraduate Medical Institute, Shaikh Zayed Hospital Lahore, for the period of Six months. Material \& Methods: 30 samples of diagnosed breast cancer were included in study. Formalin fixed paraffin embedded wax block were taken for immunohistochemical staining of ER, PR \& HER-2/neu. Results: Out of 30 cases, racially 29 were Punjabi and 1 was Pakhtun. There were 23 mastectomy samples and 7 needle core biopsies. Out of 30 cases, 29 were Infiltrating Ductal Carcinoma. Grade I, II, III 13.3\%, $66.7 \%$ and $20 \%$ respectively and only one case was of Carcinosarcoma $(p<0.01)$. Overall immunoexpression for ER, PR and HER-2/neu were 33.3\% $(\mathrm{p}<0.01), 56.7 \%(\mathrm{p}<0.05)$ and $73.3 \%$ respectively. Triple positive (TP) cases were $23.3 \%$ and triple negative (TN) were $10 \%$. Regarding ER expression in infiltrating ductal carcinoma, $63.3 \%$ were ER negative and $33.3 \%$ were ER positive and comparison was statistically highly significant $(\mathrm{p}<0.01)$.PR expression in infiltrating ductal carcinoma showed $56.7 \%$ PR positive and $40 \%$ PR negative which was statistically significant $(\mathrm{p}<0.05)$. There is negative correlation of HER-2/neu positive and ER positive and positive correlation of HER-2/neu positive and PR positive cases.
\end{abstract}

Conclusion: There is inverse correlation of HER-2/neu positive and ER positive and positive correlation of HER-2/neu positive and PR positive cases.

Key words: ER, PR, HER-2/neu, Breast receptors, Breast carcinoma.

\section{INTRODUCTION}

W orldwide, breast cancer is the most common type of cancer and the most common cause of cancer-related mortality among women. In women, breast cancer accounts for $26 \%$ of new cases of cancer and $15 \%$ of cancer deaths, second only to lung cancer as a cause of cancer-specific death. Although incidence rates (all races combined) are substantially higher for women aged 50 and older $(375.0$ per 100,000) compared with women younger than 50 years $(42.5$ per 100,000$)$, approximately $23 \%$ of breast cancers are diagnosed in women younger than 50 years, because those women represent $73 \%$ of the female population. ${ }^{1}$

In Pakistan as well, breast is the most common site of female cancer, accounting for one third of female cancer (age-standardized Rate $=51.7$ ). Bhurgri et al (2000) has reported for Karachi (Pakistan) the highest incidence of breast cancer for any Asian population except Jews in Israel. ${ }^{2}$ Armed Force Institute of Pathology (AFIP), Rawalpindi is publishing regular cancer data in form of decade monographs. ${ }^{3}$

Prognosis and management of breast cancer is influenced by the classic variables such as histologic type and grade, tumor size, lymph node status, status of hormonal receptors- estrogen receptor (ER) 
and progesterone receptor $(\mathrm{PR})$ of the tumor, and, more recently, HER-2/neu status. ${ }^{5}$ The histopathological examination of the breast cancer is based on the morphological features but more specific prognostic information about its biology are obtained from the immunohistochemical (IHC) testing of the human epidermal growth factor receptor HER2/neu, estrogen receptors (ER) and progesterone receptors (PR). Expression levels of the estrogen, progesterone and HER2/neu receptors which characterize clinically distinct breast tumors have been shown to change during disease progression and in response to systemic therapies. ${ }^{6}$

HER-2/neu, also known as c-erbB-2 (HER-2/neu), a proto-oncogene located on chromosome 17, is amplified and/or the protein (HER-2/neu) is over expressed in $15 \%$ to $25 \%$ of invasive breast carcinomas and is associated with a worse clinical outcome. In contrast, ER is expressed in $70 \%$ to $95 \%$ of invasive lobular carcinomas and in $70 \%$ to $80 \%$ of invasive ductal carcinomas, and PR is expressed in $60 \%$ to $70 \%$ of invasive ductal carcinomas. ${ }^{4}$ Expression of ER and/or PR generally is associated with a better outcome. Survival and response to hormone therapy are most favorable among women with tumors positive for both ER and $\mathrm{PR}$, intermediate for tumors discordant on receptor status, and least favorable for tumors negative for both. $^{7}$ The interrelationship of ER, PR, and HER$2 /$ neu has an important role in the management of breast cancer. It has been shown that patients with breast carcinoma over expressing HER-2/neu do not respond to tamoxifen therapy. Although HER-2/neu expression is generally inversely correlated with ER and PR expression, the precise extent of its inverse relationship and its association with classic histologic prognostic indicators has not been studied systematically in a large series of cases. ${ }^{8}$

The hormone receptor expression measured by IHC is accepted as standard evaluation method all over the world, but the cutoff point in immunehistochemical (IHC) evaluation is still controversial. ${ }^{9}$

The randomized population coming to Shaikh Zayed Hospital is different (majority from Punjab) compared to any other tertiary care center in city. As no data is available from this institute on breast cancer receptor status, so this study may help to determine the behavior of breast cancer and their prognostic attributes in patients coming to Shaikh Zayed Hospital.

The Receptor Status: The receptor status of breast cancers has traditionally been identified by immunohistochemistry, which stains the cells based on the presence of estrogen receptors (ER), progesterone receptors (PR) and HER-2/neu receptors. ${ }^{10}$

Receptor status is used to divide breast cancer into several molecular classes:

- Basal-like ( $13 \%$ to $25 \%$ of NST carcinomas), which are ER-ve, PR-ve and HER-2/neu-ve (triple negative, TN). These tumors are generally high grade with high proliferative index and aggressive behavior. Most BRCA1 breast cancers are basallike TN. ${ }^{11}$

- Luminal A (40\% to $55 \%$ of NST carcinomas), which are ER and PR +ve, HER-2/neu negative and low grade. These tumors are generally slow growing and better respond to hormonal treatment.

- Luminal B ( $15 \%$ to $20 \%$ of NST carcinomas), which are ER+ ve, PR +ve and over expresses HER-2/neu (Triple Positive). These are major group of ER + vecancers with higher grade and higher proliferative rate, may respond to chemotherapy. ${ }^{12}$

- HER-2/neu Positive (7\% to $12 \%$ of NST carcinomas), which have amplified ERBB2, over express HER-2/neu protein and ER -ve. These cancers are often poorly differentiated and associated with high frequency of brain metastasis.

Claudin-low/ Normal breast-like (6\% to $10 \%$ of NST cancers), a more recently described class that is often triple-negative but which may be distinct in that this subset of TN also has low cell-cell junction protein and has frequent lymphocytic infiltration. Usually well-differentiated ER + ve and HER-2/neu negative. ${ }^{13}$

\section{MATERIAL AND METHODS}

The study was conducted at Department of Histopathology, Shaikh Zayed Federal Postgraduate Medical Institute, Shaikh Zayed Hospital, Lahore. The specimens of the patients with breast malignancies received in Histopathology Department, Shaikh Zayed Hospital were enrolled in study. The patient were accessed in the relevant ward, explained the objective of study, benefits of tests, sought informed / written consent, the patient's specimen were enrolled in study for ER, PR and HER-2/neu status and these tests were carried out free of cost for the patient.

\section{Inclusion Criteria}

- Specimens of female patients (only) of reproductive age, peri-menopausal and post menopausal with invasive breast carcinomas diagnosed by histopathology as primary tumor. 
- Tissue fixation should be done with $10 \%$ neutral buffered formalin for at least 6-72 hours.

- Needle core biopsy, Trucut biopsy, lumpectomy, mastectomy

\section{Exclusion Criteria}

- In situ carcinoma.

- Patients receiving neo-adjuvant therapy.

- Recurrent carcinoma.

- Cytological specimen/smear

\section{Sample Size}

The sample size were estimated by using 5\% level of significance, $80 \%$ power of test with expected expression of ER $49.1 \%$ and $78.17 \%$; and PR in $24.3 \%$ and $53.13 \%$ in HER-2 +ve and HER-2 -ve cases respectively. The estimated size was 30 . Thirty (30) cases fulfilling the criteria were included.

Reagents and Procedure: A variety of detection kits are available in market, Super Senstive ${ }^{\mathrm{TM}}$ OneStep Polymer-HRP Detection System by "Biogenex", was used for this study following standard procedure of staining and demonstration.

\section{Estrogen Receptor Ab-11 (Clone 1D5)}

Ab-11 strongly stains the nucleus of epithelial cells in breast carcinomas.

Mol. Wt. of Antigen: $67 \mathrm{kDa}$

Progesterone Receptor Ab-9 (Clone 1A6)

Description: Human progesterone receptor (PR) exists in two forms: $116 \mathrm{kDa}$ (B-form) and $81 \mathrm{kDa}$ (A-form).

HER-2/neu/c-erbB-2 (Clone SP3)

Clone SP3 is excellent for staining of formalin/ paraffin.

Cellular Localization: Cell membrane

\section{Assessment of staining:}

- ER/PR Nuclear Staining Scoring: Estrogen and progesterone receptors are located in the nucleus of breast epithelial and carcinoma cells. The percentage of tumor cells demonstrating positive reactivity, their intensity of staining results combined together and simple arithmetical number, either of these two methods has been previously in practice. Recently simpler 'Allred score' methods have been promoted which appear equally effective clinically. This uses either a direct count of the proportion of tumor nuclei that take up stain or a simple combination of $\%$ cells staining plus a measure of intensity of stain. The scoring system in table is a simple additive system giving a range from 0 to 8 (Minimum score 0 , maximum score 8 ).
Allred Score system

\begin{tabular}{|l|l|}
\hline $\begin{array}{l}\text { Score for Proportion } \\
\text { staining }\end{array}$ & $\begin{array}{l}\text { Score for staining } \\
\text { intensity }\end{array}$ \\
\hline $0=$ No Nuclear staining & $0=$ No staining \\
\hline $1=<1 \%$ Nuclei staining & $1=$ Weak staining \\
\hline $\begin{array}{l}2=1-10 \% \text { Nuclei } \\
\text { staining }\end{array}$ & $2=$ Moderate staining \\
\hline $\begin{array}{l}3=10-33 \% \text { Nuclei } \\
\text { staining }\end{array}$ & $3=$ Strong staining \\
\hline $\begin{array}{l}4=33-66 \% \text { Nuclei } \\
\text { staining }\end{array}$ & \\
\hline $\begin{array}{l}5=66-100 \% \text { Nuclei } \\
\text { staining }\end{array}$ & \\
\hline
\end{tabular}

- HER-2/neu membranous Staining Score: Grading of the Immunohistochemical Staining for HER-2/neu Over Expression

\begin{tabular}{|l|c|c|}
\hline \multicolumn{1}{|c|}{ Staining Pattern } & Score & $\begin{array}{c}\text { HER-2/neu over } \\
\text { expression } \\
\text { assessment }\end{array}$ \\
\hline $\begin{array}{l}\text { No staining is observed or } \\
\text { membrane staining is } \\
\text { observed in less than 30\% } \\
\text { of the tumor cells. }\end{array}$ & 0 & Negative \\
\hline $\begin{array}{l}\text { A faint/barely perceptible } \\
\text { membrane staining is } \\
\text { detected in more than } \\
30 \% \text { of the tumor cells. }\end{array}$ & $1+$ & Negative \\
$\begin{array}{l}\text { The cells are only stained } \\
\text { in part of their membrane. }\end{array}$ & & \\
\hline $\begin{array}{l}\text { A weak to moderate } \\
\text { complete membrane } \\
\text { staining is observed in } \\
\text { more than 30\% of the }\end{array}$ & $2+$ & Weakly Positive \\
tumor cells. & & \\
\hline $\begin{array}{l}\text { A strong complete } \\
\text { membrane staining is } \\
\text { observed in more than } \\
30 \% \text { of the tumor cells. }\end{array}$ & $3+$ & Strongly Positive \\
\hline
\end{tabular}

If the results are either $3+$ or 0 , the determination can be safely stopped there, since the correlation with gene over expression or lack of it, respectively, as measured by FISH, is nearly $100 \%$. If the immunotest gives instead a result of $1+$ or $2+$, the performance of FISH is recommended.

Statistical analysis:

Statistical analysis was conducted using SPSS version 16 
RESULTS

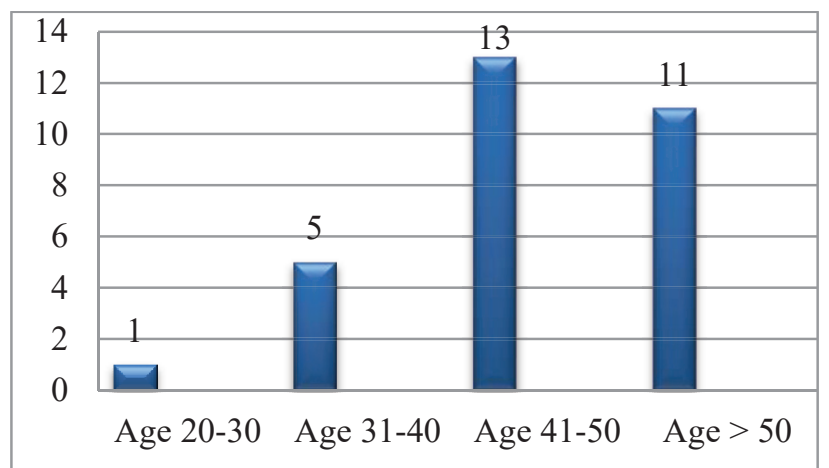

Fig-1: Age distribution of cases $(n=30)$

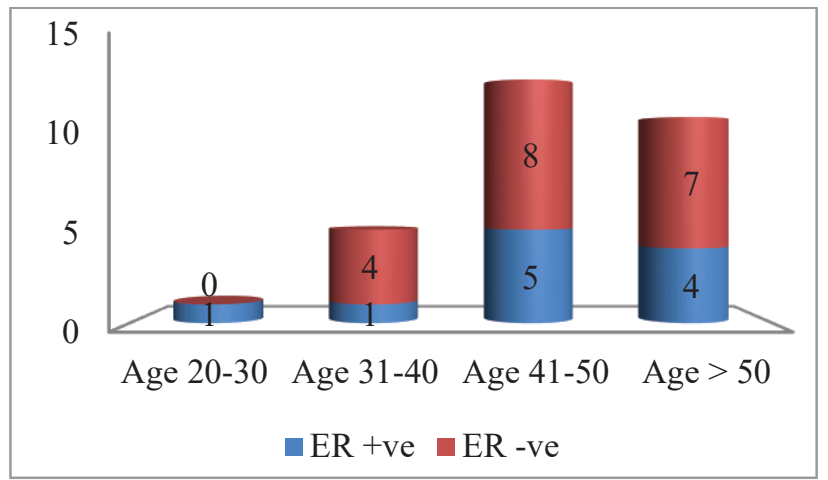

Fig-2: Estrogen receptor status, age distribution $(n=30)$

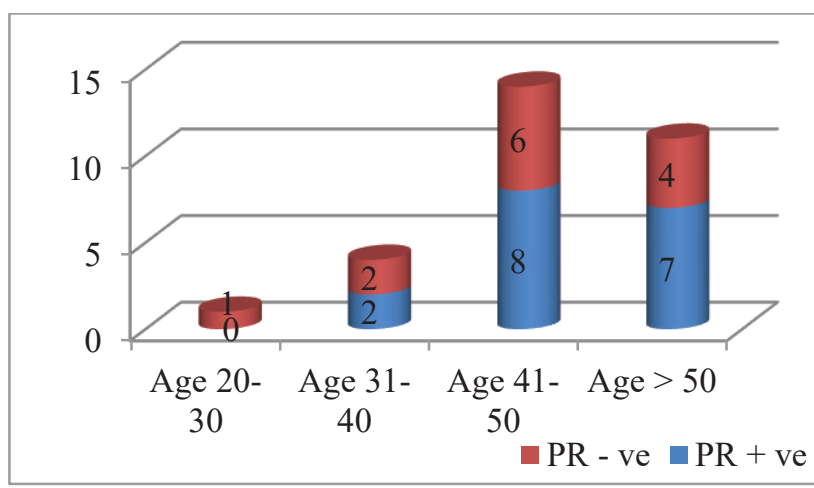

Fig-3:Progesterone receptor status, age distribution $(n=30)$

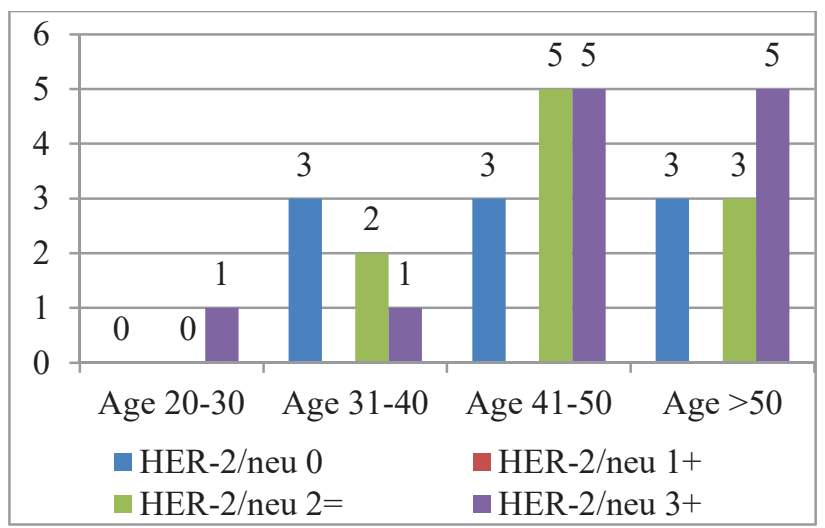

Fig-4: HER-2/neu over-expression with age distribution

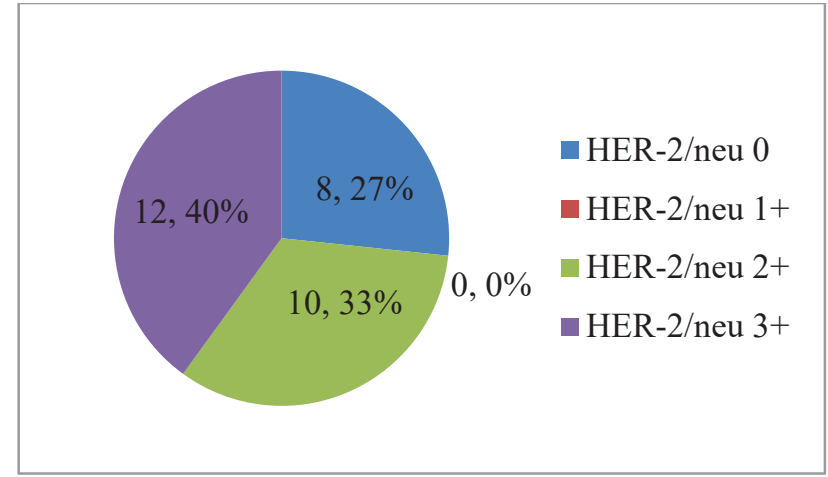

Fig-5: HER-2/neu score in breast carcinomas $(\mathrm{n}=30)$

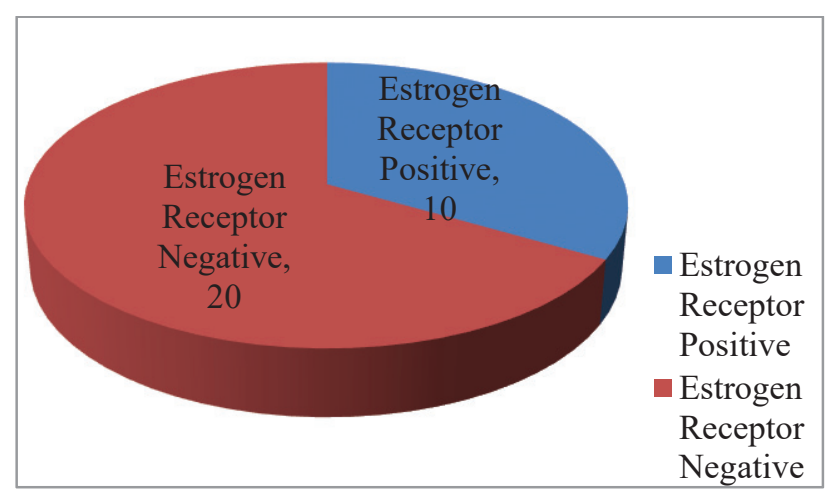

Fig-6:Estrogen receptor status of breast malignancies $(n=30)$

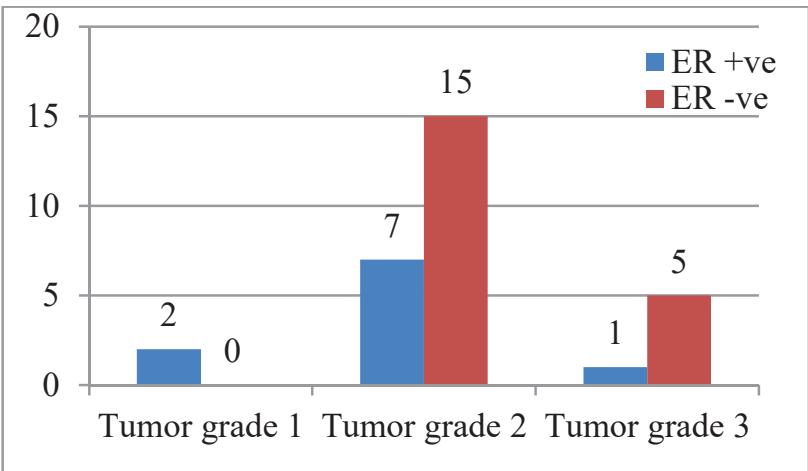

Fig-7: ER Status with tumor grades $(n=30)$

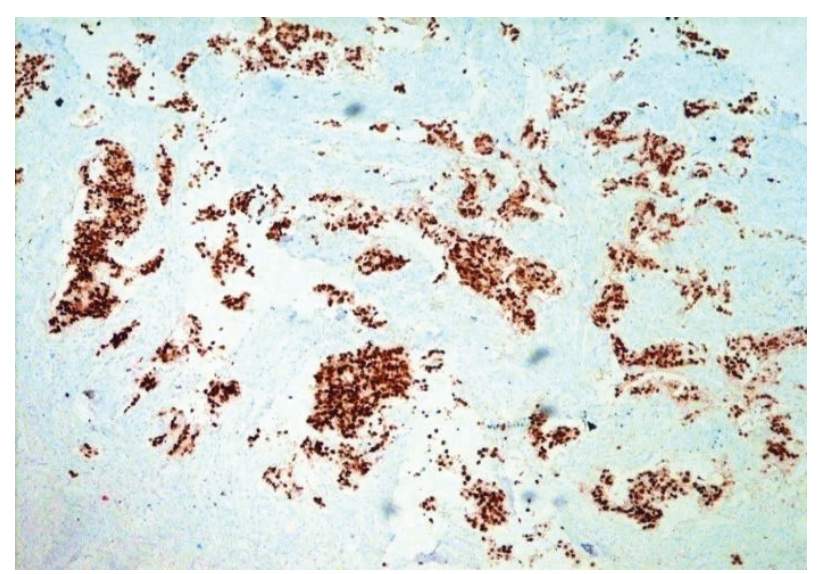

Fig-8: Photomicrograph Estrogen Receptor (ER) Positive, IH. $4 \times 10$ 


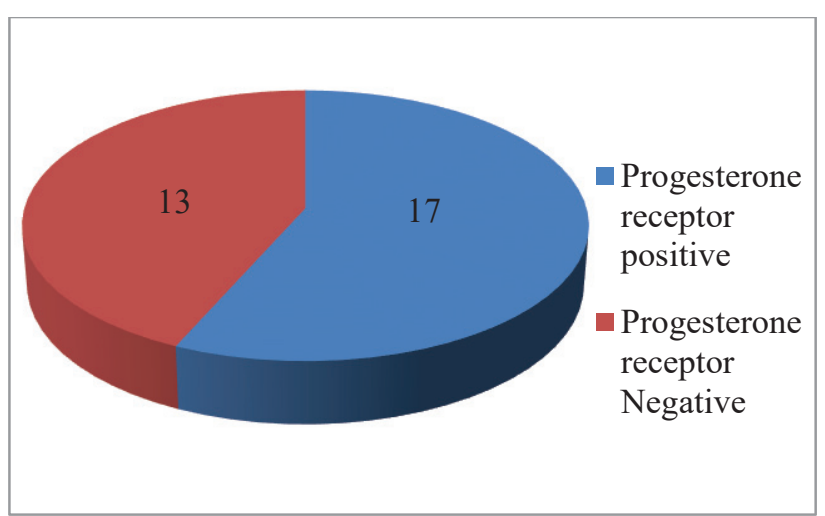

Fig-9: Progesterone receptor status in breast malignancies $(n=30)$

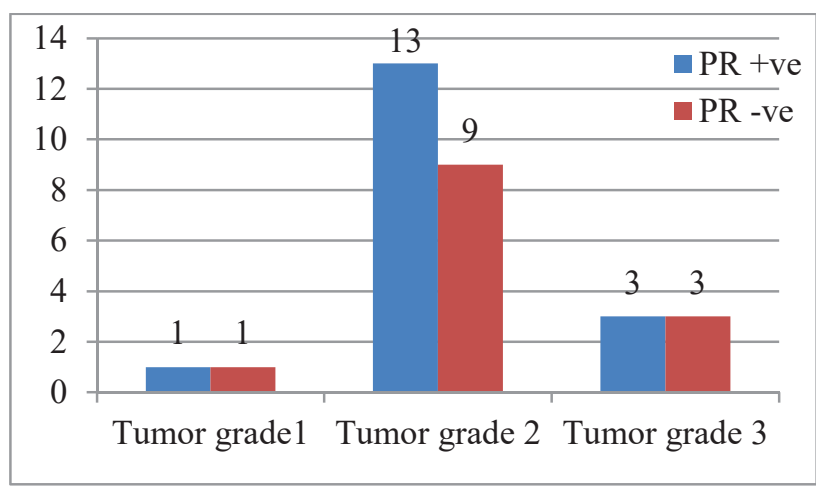

Fig-10: PR Status with tumor grades $(n=30)$

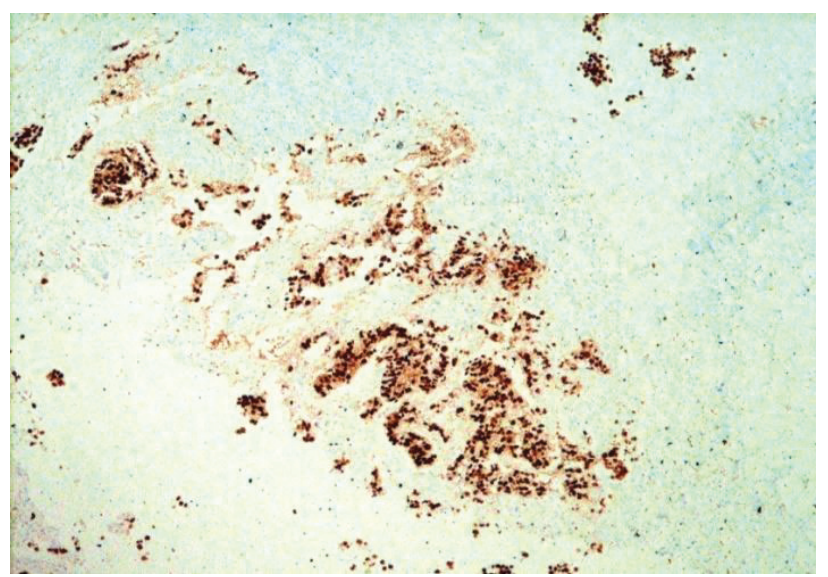

Fig-11: Photomicrograph Progesterone Receptor (PR) Positive, IH. $4 \times 10$

\begin{tabular}{|c|c|c|c|c|c|c|c|}
\hline \multirow{2}{*}{$\begin{array}{c}\text { Histological } \\
\text { Subtypes }\end{array}$} & \multicolumn{3}{|c|}{ HER-2/neu } & \multicolumn{2}{|c|}{ ER } & \multicolumn{2}{|c|}{ PR } \\
\hline & $\begin{array}{c}\text { Strong } \\
+ \text { ve }\end{array}$ & $\begin{array}{l}\text { Weak } \\
\text { +ve }\end{array}$ & -ve & $+v e$ & -ve & +ve & -ve \\
\hline $\begin{array}{c}\text { Ductal } \\
\text { Carcinoma }\end{array}$ & $\begin{array}{c}12 * \\
(40 \%)\end{array}$ & $\begin{array}{c}09^{*} \\
(30 \%)\end{array}$ & $\begin{array}{c}08 \\
(26.7 \%)\end{array}$ & $(33.3 \%$ & $19 \%$ & $\begin{array}{l}17 * * \\
(56.7 \%)\end{array}$ & $\begin{array}{c}12 \\
(40 \%)\end{array}$ \\
\hline \begin{tabular}{|c|}
$\begin{array}{c}\text { Carcinosar- } \\
\text { coma }\end{array}$ \\
\end{tabular} & -- & \begin{tabular}{|c|}
01 \\
$(3.3 \%)$ \\
\end{tabular} & -- & Nil & \begin{tabular}{|c|}
01 \\
$(3.3 \%)$ \\
\end{tabular} & Nil & \begin{tabular}{|c|}
01 \\
$(3.3 \%)$ \\
\end{tabular} \\
\hline $\begin{array}{c}\text { Total } \\
\text { Subjects }\end{array}$ & $\begin{array}{c}12 \\
(40 \%)\end{array}$ & $\begin{array}{c}10 \\
(33.3 \%\end{array}$ & $\begin{array}{c}08 \\
(26.7 \%)\end{array}$ & $(33.3 \%$ & $\begin{array}{c}19 \\
(66.6 \%)\end{array}$ & $\begin{array}{c}17 \\
(56.7 \%)\end{array}$ & $\begin{array}{c}13 \\
(43.3 \%)\end{array}$ \\
\hline
\end{tabular}

Table-1: Frequency of HER-2/neu, ER \& PR in various histological types $(\mathrm{n}=30) \quad(* \mathrm{P}<0.01)(* * \mathrm{P}<0.05)$

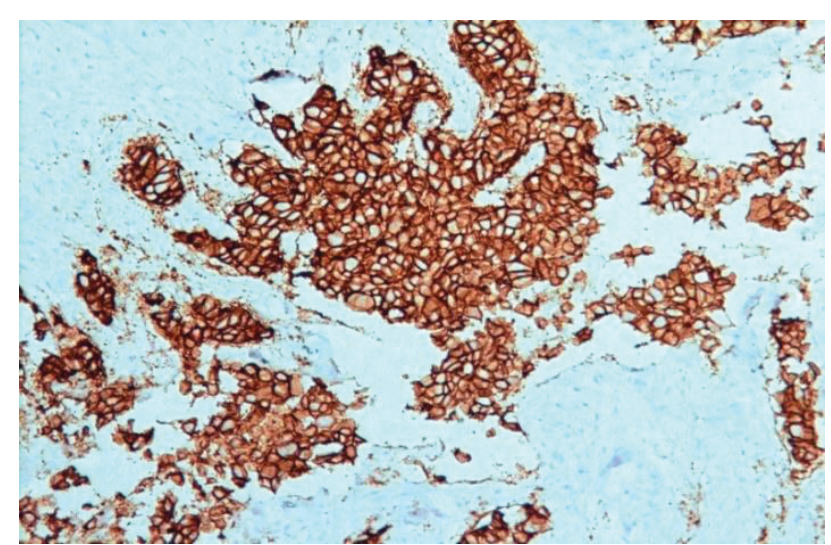

Fig-12: Photomicrograph 12: HER-2/neu 3+, IH. 10X10

\begin{tabular}{|c|c|c|}
\hline Receptors & $\begin{array}{c}\text { No. of } \\
\text { cases }\end{array}$ & \%age \\
\hline ER/PR+ve,HER-2/neu +ve & 07 & $23.3 \%$ \\
ER/PR+ve,HER-2/neu -ve & 01 & $3.3 \%$ \\
ER/PR-ve,HER-2/neu +ve & 08 & $26.7 \%$ \\
ER/PR-ve,HER-2/neu -ve & 03 & $10 \%$ \\
\hline ER/PR +ve & 08 & $26.7 \%$ \\
ER/PR -ve & 11 & $36.7 \%$ \\
ER+/PR-ve & 02 & $6.7 \%$ \\
ER-/PR +ve & 09 & $30 \%$ \\
\hline HER-2/neu +ve & 22 & $73.3 \%$ \\
HER-2/neu -ve & 08 & $26.7 \%$ \\
\hline
\end{tabular}

Table-2: Receptor Status in Different Cases $\quad(\mathrm{P}<0.01)$

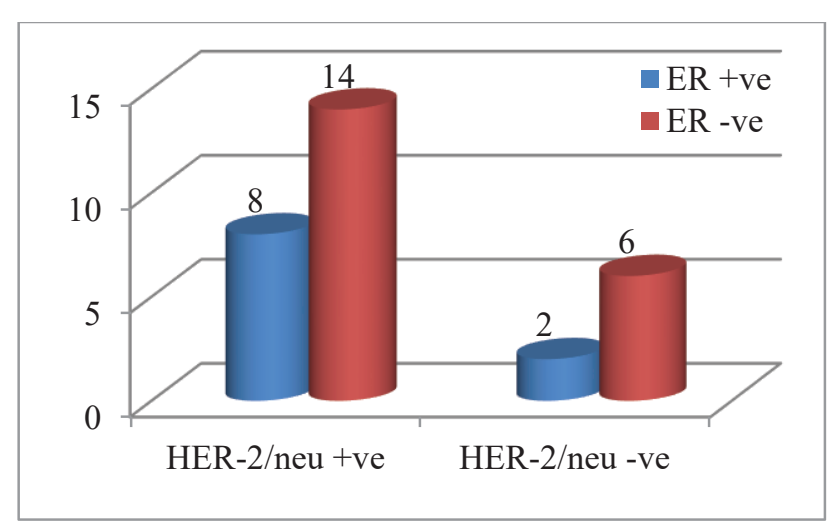

Fig-13: Comparison of Her -2/neu status with ER Status

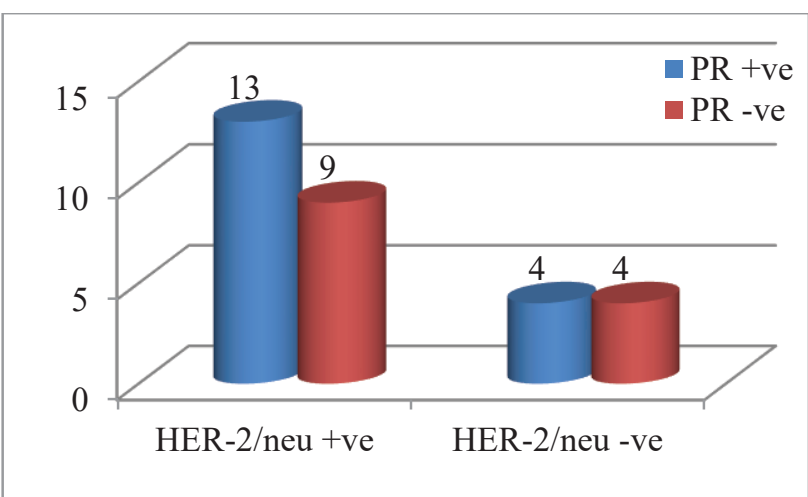

Fig-14: Comparison of Her -2/neu status with PR Status 


\begin{tabular}{|c|c|c|}
\hline & $\begin{array}{c}\text { HER-2/neu +ve } \\
(\mathrm{n}=22)\end{array}$ & $\begin{array}{c}\text { HER-2/neu-ve } \\
(\mathrm{n}=08)\end{array}$ \\
\hline Total & $22(73.3 \%)$ & $08(26.7 \%)$ \\
\hline Age (I & 49.2 & 48.6 \\
\hline Grade & $\begin{array}{ll}1 & 02(9.1 \%) \\
2 & 16^{*}(72.7 \%) \\
3 & 04(18.2 \%)\end{array}$ & \begin{tabular}{|ll}
1 & Nil \\
2 & $06 *(75 \%)$ \\
3 & $02(25 \%)$
\end{tabular} \\
\hline ER Ex & $\begin{array}{l}\text { ER-ve } 14 *(63.6 \%) \\
\text { ER+ve } 08(36.4 \%)\end{array}$ & $\begin{array}{l}\text { ER-ve } 06 *(75 \%) \\
\text { ER+ve } 02(25 \%)\end{array}$ \\
\hline & $\begin{array}{l}\text { PR-ve } 09(40.9 \%) \\
\text { PR+ve } 13 *(59.1 \%)\end{array}$ & $\begin{array}{ll}\text { PR-ve } & 04(50 \%) \\
\text { PR+ve } & 04(50 \%)\end{array}$ \\
\hline
\end{tabular}

Table-3: Expression of HER-2/neu with ER/PR Status

\begin{tabular}{|c|c|c|}
\hline $\begin{array}{c}\text { Correlation } \\
\text { with }\end{array}$ & r value & Significance \\
\hline $\begin{array}{c}\text { HER-2/neu +ve } \\
\text { Vs } \\
\text { ER +ve }\end{array}$ & $\begin{array}{c}(-0.682) \\
\text {-ve correlation }\end{array}$ & $\mathrm{P}<0.01(\mathrm{HS})$ \\
\hline $\begin{array}{c}\text { HER-2/neu +ve } \\
\text { Vs } \\
\text { PR +ve }\end{array}$ & $\begin{array}{c}(0.821) \\
+ \text { ve correlation }\end{array}$ & $\mathrm{P}<0.01(\mathrm{HS})$ \\
\hline
\end{tabular}

Table-4: Correlation of HER-2/neu positive with ER/PR expressions

\section{DISCUSSION}

In the study of Sofi at el (2012), the receptor status was available in 101 cases, $67(66.3 \%)$ cases were ER positive, 64 (63.4\%) cases were PR positive, 61 $(60.4 \%)$ cases were both ER and PR positive, 31 $(30.7 \%)$ cases were both ER and PR negative, 6 (5.9\%) cases were ER positive and PR negative and $3(2.9 \%)$ cases were ER negative and PR positive. While in this study, out of 30 cases, $10(33.3 \%)$ were ER positive and 17 (56.6\%) were PR positive, and in $8(26.6 \%)$ were both ER and PR positive while $20(66.7 \%)$ were ER negative, $13(43.3 \%)$ were PR negative and $11(36.7 \%)$ were ER, PR negative. ${ }^{14}$ IDC (Infiltrating ductal carcinoma) was the predominant morphological category with IDC NOS (not otherwise specified). Modified Bloom Richardson Grading was applicable to 119 cases, of which $9(7.6 \%)$ cases were grade 1, $62(52.1 \%)$ cases were grade 2 and $48(40.3 \%)$ cases were grade 3 (Sofi at el 2012).

While in this study, 29 (96.6\%) were Infiltrating Ductal Carcinoma and $1 \quad(3.3 \%)$ was carcinosarcoma. Regarding grade, 02 (6.6\%), were in grade $1,22(73.3 \%)$ were in grade 2 and $6(20 \%)$ in grade 3 and difference was highly significant when comparing grade 2 with other grades $(\mathrm{p}<$ 0.01). ${ }^{14}$ Regarding HER-2/neu expression, out of 22 HER-2/neu +ve cases, 08(36.4\%) were ER +ve and $13(59.1 \%)$ were PR +ve. There is negative correlation of HER-2/neu +ve and ER+ve cases while +ve correlation of HER-2/neu +ve and PR +ve cases.

A retrospective analysis was performed on 267 cases of breast cancer referred for treatment at King Hussein Cancer Center, Jordan between the period of June 2003 and June 2004. ${ }^{15}$ Standard immune stains were used for evaluation of hormone receptors and HER-2/neu. In addition, evaluation of HER-2/neu was done by FISH in selected cases. Of these 267 cases, $240 \quad(89.9 \%)$ were ductal carcinomas of various histological grades, 122 $(50.8 \%)$ of which were ER-positive, 138 (57.5\%) PR positive and 42 (17.5\%) HER-2/neu-positive. Twenty two $(8.2 \%)$ of all cases were lobular carcinomas, $15(68 \%)$ of which were ER-positive, 20 (90.9\%) PR positive and 3 (13.6\%) HER-2/neupositive. Five $(1.9 \%)$ of the total cases were of mixed lobular and ductal types, $4(80 \%)$ of which were ER-positive, 3 (60\%) PR-positive and none were positive for HER-2/neu

Another study was conducted at Department of Histopathology, Armed Forces Institute of Pathology, Rawalpindi. Out of 535 cases, there were $481(89.9 \%)$ cases of infiltrating ductal carcinoma with mean age of 48 years and mean tumor size of $4.4 \mathrm{~cm}$. Tumor grade II was seen in $68 \%$ cases and lymph node metastases were present in $65 \%$ cases. HER-2/neu expression was seen in 31\% cases, while ER and PR expression was seen in $72.3 \%$ and $62.6 \%$ respectively. ER and PR showed inverse association with HER-2/neu while positive association was seen with lymph node metastases $(\mathrm{p}<0.05)$. No association was seen between tumor size and tumor grade. Joint ER and PR expression also showed a higher number (73.5\%) of HER-2/neu negative cases. ${ }^{16}$

Study conducted at Department of Pathology and Microbiology, Aga Khan University Hospital; Mean age of the patients was 48.3 years. The left breast was more commonly involved (57\%). Tumor size ranged from 0.3 to $15.0 \mathrm{~cm} ; 12 \%$ were $>2.0$ and $35.3 \%$ were $>5.0 \mathrm{~cm}$ in diameter. The predominant morphology was infiltrating ductal carcinoma $(85.3 \%)$. The majority of the cases presented as grade II $(55.3 \%)$ lesions with tumor necrosis $(70 \%)$ and lymph node involvement (71.3\%). ER and PR were positive in $32.7 \%$ and $25.3 \%$ cases respectively. HER-2/neu was positive $(3+)$ in $24.7 \%$. ER positivity increased and HER-2/neu positivity decreased with rising age. ER and PR expression was significantly lower in HER-2/neu positive as compared with HER-2/neu negative tumors (ER $83.8 \%$ vs $69.8 \%$; PR $91.9 \%$ vs $77.8 \%$ ). In the HER-2/neu positive tumors, ER and PR expression in high grade tumors was significantly 
decreased compared with intermediate grade tumors (ER $5.6 \%$ vs 10.5 ; PR $0 \%$ vs $5.3 \%$ ). ER expression in the HER-2/neu positive, large sized tumors was also significantly decreased compared with smaller tumors (ER 6.3\% vs 11.8).

In regard to HER-2/neu, the results appear to be within the commonly reported rates of $20 \%$ to $30 \%$. Less than $20 \%$ or more than $30 \%$ of HER-2/neu over-expression was reported by many studies. ${ }^{17}$

The overall co-expression of hormones receptors in another study were found as follow: ER $+\mathrm{ve} / \mathrm{PR}+\mathrm{ve}$ (39.41\%), ER +ve/PR -ve(13.86\%), ER$/ \mathrm{PR}+(0.72 \%)$ and ER-/PR-(45.98\%). One of the interesting results in our study was that ER-/PR+ which found only in one case out of 137 malignant cases. Such finding was reported by Nicholas et al, ${ }^{18}$ he found only one case out of 192 with ER-ve have $\mathrm{PR}+\mathrm{ve}$ with weak positive immune staining.

These results were strongly challenged by Colomer et al. ${ }^{19}$ they reported $\mathrm{ER}+/ \mathrm{PR}+, \mathrm{ER}+/ \mathrm{PR}-, \mathrm{ER}-$ $/ \mathrm{PR}+$, and ER-/PR- in $46 \%, 19 \%, 7 \%$ and $28 \%$, respectively. In another study, $63.9 \%$ of white American women with breast cancer were $\mathrm{ER}+/ \mathrm{PR}+, 12.8 \% \mathrm{ER}+/ \mathrm{PR}-, 3.6 \% \mathrm{ER}-/ \mathrm{PR}+$ and $19.8 \%$ ER-/PR- while among black American women $48.3 \%$ were $\mathrm{ER}+/ \mathrm{PR}+, 11.8 \% \mathrm{ER}+/ \mathrm{PR}-, 5 \%$ ER-/PR+ and 34.8\% ER-/PR-.

One well defined subtype of breast cancer is characterized by lack of ER, PR and HER-2/neu over-expression/ or amplification that's called TN tumors. ${ }^{20}$ It constitutes $10 \%$ to $20 \%$ of breast cancer. The inverse association between hormones receptors and HER-2/neu leads to lower or absent hormone receptors in women with HER-2/neu positive breast cancers. This is one of the reasons why women who over-express HER-2/neu may be resistant to Tamoxifen. ${ }^{21}$ These results confirmed that the presence of ER and PR receptors in human breast cancer cell lines resulted in a strong reduction of HER-2/neu protein over-expression. These findings are in agreement with other reports in the literature, which showed an inverse significant association between hormones receptors expression and HER2 over-expression.

Among the various proposed prognostic factors, HER-2/neu over-expression has been found to predict early metastasis, shortened disease-free survival, overall survival, poor clinical outcome with therapy and early recurrence in breast carcinoma. The association between amplified HER-2/neu gene and a shorter disease-free survival (DFS) as well as overall survival, has been confirmed by several studies. This subset of HER$2 /$ neu positive breast cancer also shows resistance to certain forms of chemotherapy like $\mathrm{CMF}$ (cyclophosphamide, methotrexate and 5Fluorouracil) and tamoxifen, while showing sensitivity to others like doxorubicin. HER-2/neu has been found to be associated with other poor prognostic factors including age, lymph node status, tumor size and histological grading. Trastuzumab, a humanized antibody to HER-2/neu protein is being used as a therapy for patients with advanced breast cancer. $^{21}$

\section{CONCLUSION}

- Out of 30 cases 29 were Infiltraing ductal carcinoma, grade 1 , grade 2 , grade 3 were 02 (6.6\%), $22(73.3 \%)$ and $06(20 \%)$ respectively.

- Only one case was that of carcinosarcoma grade 2

- HER-2/neu over expression was found in $73.3 \%$ (22).

- Age was found to be statistically associated with HER-2/neu positivity and young patients had HER-2/ neu positive breast carcinoma.

- $23.3 \%(07)$ cases are triple positive disease and $10 \%(03)$ are with triple negative disease.

- Among HER-2/neu +ve cases, $72.7 \%$ (16) were of IDC grade 2.

- In HER-2/neu +ve cases, 36.4\% (8) were ER +ve while $63.6 \%$ (14) were ER-ve.

- In HER-2/neu +ve cases, 59.1\% (13) were PR +ve while $40.9 \%$ (09) were PR-ve.

- $63.6 \%$ (14) cases were with ER -ve in HER$2 /$ neu +ve subjects.

- $59.1 \%$ (13) cases were with PR +ve in HER$2 /$ neu +ve subjects.

- There is inverse correlation of HER-2/ neu +ve and ER +ve subjects and positive correlation of HER-2/ neu +ve with PR + ve cases.

- In IDC, 21 cases were with HER-2/ neu +ve (12 cases +3 \& 9 cases +2 ) and 08 cases were with HER-2/ neu -ve. 10 cases were with ER +ve and 19 cases were with ER -ve. 17 cases were with $\mathrm{PR}+\mathrm{ve}$ and 12 cases were with PR -ve. Only one case of Non-IDC (Carcinosarcoma) is ER/PR -ve and HER-2/ neu +2 in this study.

- Out of 07 triple +ve cases, 05 were grade 2 IDC with age groups between 40-60 years. One triple + ve case was grade 1 IDC with age 45 years and one triple $+v$ ve case was grade 3 IDC with age 52 years.

- All 03 triple -ve cases were of IDC grade 2 with age group $\leq 50$ years.

\section{Limitation of study:}

This study is based on immunohistochemical method for detection of estrogen receptor, 
progesterone receptors and HER2/neu over expression. HER $2 /$ neu $2+$ breast carcinomas on immunohistochemistry are equivocal in their estimation, for such cases florescent in-situ hybridization (FISH) is the standard method for HER2/neu over expression. This study by its very design is based on immunohistochemical method, so is deficient in conclusive and reliable expression of HER $2 /$ neu $2+$ cases.

In this study for HER2/neu estimation membrane staining of $>30 \%$ of tumor cells was employed, which has been recently revised to $>10 \%$ of tumor cells by College of American Pathologist (CAP) in its recent, "Template for reporting results of biomarker testing of specimen from patient with carcinoma of breast" version 1.3.0.0 posting date August 2019.

\section{REFERENCES}

1. Gloyeske NC, Dabbs DJ, Bhargava R. Low ER + Breast Cancer Is This a Distinct Group? 2014; 697-701.

2. Bhurgri Y, Bhurgri A, Usman A, Sheikh N, Faridi N. Patho-epidemiology of Lung Cancer in Karachi (1995-2002). 2006; 1(December 2014).

3. Jamal S, Mamoon N, Mushtaq S, Luqman M. Carcinoma of the Male Breast: a Study of 141 cases from Northern Pakistan. 2016; (January).

4. Ghoncheh M, Pournamdar Z, Salehiniya H. Incidence and Mortality and Epidemiology of Breast Cancer in the World. 2016; (June 2017).

5. Iqbal BM, Buch A. Hormone receptor (ER, PR, HER2/neu) status and proliferation index marker (Ki-67) in breast cancers: Their oncopathological correlation, shortcomings and future trends. 2016.

6. Iqbal N, Iqbal N. Human Epidermal Growth Factor Receptor 2 (HER2) in Cancers: Overexpression and Therapeutic Implications. 2014

7. Badowska-kozakiewicz AM, Patera J, Sobol M. The role of oestrogen and progesterone receptors in breast cancer-immunohistochemical evaluation of oestrogen and progesterone receptor expression in invasive breast cancer in women.

8. Bulut N, Altundag K. Does estrogen receptor determination affect prognosis in early stage breast cancers? 2015; 8(11):21454-9.

9. Rugo HS, Vidula N, Ma C. Improving Response to Hormone Therapy in Breast Cancer: New Targets, New Therapeutic Options. 2019.

10. Mori R, Futamura M, Morimitsu K, Yoshida K.
Chemotherapy: Open Access Effective Hormone Therapy Reduces the Efficacy of Subsequent Chemotherapy in HormoneReceptor-Positive Metastatic Breast Cancer. 2016; 5(3).

11. Asif HM, Sultana S, Akhtar N, Rehman JU. MINI-REVIEW Prevalence, Risk Factors and Disease Knowledge of Breast Cancer in Pakistan. 2014; (July).

12. Bassir M, Fakhree A, Daryani A. Breast Cancer: Basic and Clinical Research Hormone Receptor Status in Breast Cancer and its Relation to Age and Other Prognostic Factors. 2011; (May).

13. Nadji M, Gomez-fernandez C, Ganjei-azar P. Immunohistochemistry of Estrogen and Progesterone Receptors Reconsidered Experience With 5, 993 Breast Cancers. 2005; 21-7.

14. Sofi GN, Sofi JN, Nadeem R, Shiekh RY, Khan FA, Sofi AA, et al. Estrogen Receptor and Progesterone Receptor Status in Breast Cancer in Relation to Age, Histological Grade, Size of Lesion and Lymph Node Involvement. 2012; (June 2017).

15. Baker B, Abdulla K, City M, Sughayer M, Hussein K, Salameh H. Erratum to: Histobiological comparative analysis of bilateral breast cancer. 2013; (June 2014).

16. Sharif F, Abshorshori N, Tahmasebi S, Hazrati M, Zare N, Masoumi S. The effect of peer-led education on the life quality of mastectomy patients referred to breast cancer-clinics in Shiraz, Iran 2009. 2010; 1-7.

17. Sapino A, Goia M, Recupero D, Marchiò C. Current challenges for HER2 testing in diagnostic pathology: state of the art and controversial issues. 2013; 3(May):1-9.

18. Agoff SN, Swanson PE, Linden H, Hawes SE, Lawton TJ. Androgen Receptor Expression in Estrogen Receptor - Negative Breast Cancer Immunohistochemical, Clinical, and Prognostic Associations. 2003; 725-31.

19. Colomer R. Management of metastatic breast cancer: are we prepared to cope with our own success? 2004; 2101.

20. Zubeda S, Kaipa PR, Shaik NA, Khaliq M, Vaidya S, Pavani B, et al. HER-2 / neu Status: A Neglected Marker of Prognostication and Management of Breast Cancer Patients in India. 2013; 14:2231-5.

21. Peterson NC, Servinsky MD, Christian A, Peng Z, Mann J, Dicello J, et al. NIH Public Access. 2006; 26(9): 1542-52. 


\section{The Authors:}

Dr. Muhammad Afaaq Agha

Assistant Professor,

Department of Forensic Medicine \& Toxicology, Shaikh Zayed Medical Complex, Lahore.

Dr. Asma Rasheed

Assistant Professor,

Department of Pathology,

University College of Medicine and Dentistry, The University of Lahore.

Dr. Lubna Humayun

Assistant Professor,

Department of Pathology,

University College of Medicine and Dentistry,

The University of Lahore.

Dr. Sana Tariq

Assistant Professor,

Department of Pathology,

University College of Medicine and Dentistry,

The University of Lahore.
Prof. Nasir Mehmood Chughtai

Department of Histopathology,

Shaikh Zayed Medical Complex, Lahore.

Dr. Farah Bano Niazi

Senior Demonstrator,

Department of Histopathology,

Shaikh Zayed Medical Complex, Lahore.

\section{Corresponding Author:}

Dr. Muhammad Afaaq Agha

Assistant Professor,

Department of Forensic Medicine \& Toxicology, Shaikh Zayed Medical Complex, Lahore.

E-mail: drafaakagha@gmail.com 